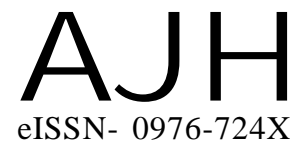

Received : 31.01.2017

Revised : 30.04 .2017

Accepted : 14.05.2017

Author for correspondence :

SUKANTA SARKAR

PG. Department of Economics,

Berhampur University, BERHAMPUR

(ODISHA) INDIA
THEASIAN JOURNALOF HORTICULTURE

Volume 12 | Issue 1 | June, 2017 | 88-90

Visit us -www.researchjournal.co.in

RESEARCH PAPER

\title{
Jackfruit production in Tripura: A land for trip of jackfruits in Bangladesh
}

\section{SUKANTA SARKAR}

ABSTRACT : Jackfruit is a traditional fruit in Tripura. Tripura jackfruit is a popular fruit ranking first in total area and annual production in Tripura. Tripura is considered to be the home of jackfruit and it is reservoir of many year-round producing genotypes. Every year huge amount of jackfruits are legal and illegally exports in Bangladesh from Tripura. The state government has already initiated a plan for reconstructing and modernisation of the plant in Nalkata. The objectives of this paper are: (a) to study jackfruit production in Tripura, and (b) to identify the business of jackfruits in Tripura.

KEY WORDS : Bangladesh, Business, Jackfruit, Production, Tripura

HOW TO CITE THIS ARTICLE : Sarkar, Sukanta (2017). Jackfruit production in Tripura: A land for trip of jackfruits in Bangladesh. Asian J. Hort., 12(1) : 88-90, DOI : 10.15740/HAS/TAJH/12.1/88-90. 